УДК 336.71

\title{
АКТУАЛЬНЫЕ ПРОБЛЕМЫ РАЗВИТИЯ БАНКОВСКИХ ТЕХНОЛОГИЙ В РЕСПУБЛИКЕ КАЗАХСТАН
}

\author{
СЕМБИЕВА Ляззат Мыктыбековна
}

доктор экономических наук, профессор кафедры финансов

Евразийского начионального университета имени Л. Н. Гумилева

ORCID ID: https://orcid.org/0000-0001-7926-0443

e-mail: sembiyeva@mail.ru

\section{ЖАГЫПАРОВА Аида Орынтаевна}

кандидат экономических наук, ассоцированный профессор кафедры финансов Евразийского национального университета имени Л. Н. Гумилева e-mail: Zhagyparova_Aida@mail.ru

\section{БЕКСУЛТАНОВА Индира Руслановна}

соискатель Евразийского национального университета имени Л. Н. Гумилева e-mail: ibeksultanova@mail.ru

Аннотация. $B$ статье охарактеризована сушность и предоставлена классификация банковских технологий, обоснована роль информационных технологий. Автором исследованы современные тенденции развития рынка банковских услуг республики Казахстан, основой предоставления которых является использование современных технологий и обоснованно перспективные направления его дальнейшего развития.

Ключевые слова: банковская технология, банковская инновация, платежная система, ичифровизачия.
Анноватція. $B$ статті охарактеризовано суть та надано класифікацію банківських технологій, обтрунтовано роль інформаційних технологій. Автором досліджено сучасні тендениії розвитку ринку банківських послуг республіки Казахстан, що базуються на використанні сучасних технологій та обтрунтовано перспективні напрями його подальшого розвитку.

Ключові слова: банківська технологія, банківська інновація, платіжна система, ичифровізація.

Рынок банковских услуг испытывает глубокие изменения и в последние годы приобрел все характеристики стремительно растущего рынка новых банковских технологий. В деятельности банков многих стран практически нет таких сфер и видов операций, в которые бы не вторгались компьютеры и другие 
электронные устройства. В настоящее время безналичная оплата товаров и услуг во многих странах достигает высших показателей, так как банковские услуги с использованием пластиковых карт стремительно развиваются. Банковские технологии неразрывно связаны с развитием экономической цифровизации. Использование современных информационных технологий позволяет банковскому сектору осуществлять экономически привлекательные операции и услуги с более низкими процентными платежами, что кардинально изменяет бизнес-процессы в банках, выводя их на принципиально иной уровень.

Современная банковская система Республики Казахстан - это сфера многообразных услуг. В нем предоставляются депозитно-ссудные, расчетно-кассовые операции и новейшие формы услуг (денежно-кредитные и финансовые инструменты, используемые банковскими структурами). Основной целью банка является увеличение доли безналичных расчетов; достижение простоты и высокой скорости обслуживания клиентов; повышение уровня и качества банковских услуг, предоставляемых организациям и населению. Достижение данной группы целей является необходимым условием развития экономики и повышения ее конкурентоспособности на международном уровне за счет перехода на инновационный путь развития. Повышение конкурентных преимуществ банков возможно, главным образом, за счет внедрения технологических, финансовых и организационных инноваций. Сегодня банки - это достаточно технологически развитые организации, которые функционируют в условиях конкуренции нового фор- мата. Так, кредитные учреждения испытывают усиливающуюся конкуренцию как со стороны традиционных участников рынка, так и со стороны новичков типа телекоммуникационных компаний или провайдеров услуг в глобальной сети. В настоящее время любой традиционный банк может совершенно неожиданно оказаться перед фактом наличия конкуренции со стороны виртуального банка, зарегистрированного за сотни тысяч километров от рынка сбыта. Актуальность темы обусловлена тем, что автоматизация бизнес-процессов уже в течение многих лет является устойчивым направлением в сфере информационных технологий.

Анализ последних исследований и публикаций.

Теоретикометодологическую основу исследования проблемных вопросов развития современных банковских технологий формируют научные работы многих отечественных и зарубежных авторов, таких, как: Аджиевой А.Ю., Астахова В.Ю., Василенко О.А., Гудковой O.В., Дворецкой Ю.А., Ермаковой Л.В., Пининой К.А., Самсоновой Е.А. и других исследователей, в которых представлено детальное толкование понятия и видов банковских технологий, приведены методологические подходы к реализации инновационных подходов в банковском обслуживании. Однако, дополнительного изучения требует вопрос оптимизации направлений развития банковских технологий в республике Казахстан.

Цель статьи заключается в исследовании ринка предоставления банковских услуг с использованием современных технологий в Республике Казахстан и обосновании наиболее 
эффективных направлений его развития.

Изложение основных результатов исследования. В мире современных коммуникаций большое место занимают банковские технологии. Они представляют собой совокупность информационных и телекоммуникационных технологий. В современной банковской сфере банковские технологии становятся все более важными с каждым днем [1]. Термин «банковская технология» начала использоваться в деловой практике относительно с недавних времен. Примерно десять лет назад его еще просто не существовало. С развитием технических средств и, в первую очередь, компьютерных технологий и средств связи, а также вследствие проявления новейших тенденций в развитии отечественной и мировой банковской системы, такие возможности не только открылись перед большинством кредитных организаций, но активнейшим образом стали внедряться в нашу жизнь. Нередко под банковской технологией предполагается автоматизация некоторых бизнес - действий, которая, по сути, представляет лишь часть общего процесса.

Понятие «банковские технологии» используется достаточно широко. Оно включает в себя такие задачи, как построение системы обслуживания клиентов по отдельным операциям и в целом по банку, комплекс средств (в том числе и технических) по реализации операций, например, с пластиковыми карточками, интерактивному обслуживанию клиентов или какихлибо других.

Банковская технология - это определенный подход банка, каким он оказывает банковскую услугу нуждающемуся в ней клиенту. Это оформлен- ный документально комплекс взаимосвязанных финансовых, организационных, юридических и других действий, что составляет полный и целостный регламент взаимодействия сотрудников банка с обслуживаемым клиентом, которая завершает единую технологию обслуживания клиентов [2].

Перечень современных банковских операций достаточно разнообразен. Более того, он может и расширяться в связи с теми или иными новациями, основанными на новых информационных или финансовых технологиях, развитие которых стимулируется необходимостью повышения рентабельности бизнеса. В то же время, как всякое действие, в соответствии с законами физики, влечет противодействие, так и развитие новых банковских технологий и основанных на них продуктах влечет за собой новые риски, учет которых требует системности и дополнительных усилий. При этом постоянно нужно помнить о потенциальной угрозе системных рисков при несбалансированном внедрении новаций [3].

К банковским технологиям относятся специальные компьютерные программы, внутренние процедуры и различные модели, связанные с управлением рисками. В этом контексте средства защиты играют очень важную роль, и для этого, используются методы криптографии. Кроме того, большое значение в сфере кредитнофинансовых учреждений придается безопасности, в том числе, применительно к информационной составляющей. Из-за таких причин, активно применяются разнообразные технические средства, для защиты кредитных 
карт, базы данных, а также банкоматов и кассовых узлов [4].

Без банковских технологий в текущее время нереально решить ни одну из задач, которые касаются управления банком, так как за прошедшие пару лет резко поменялись требования к скорости принятия решений, возрос размер операций и применяемой в процессе деятельности информации.

Эти технологии характеризуются системой способов изучения работы заведений, способствующих росту вещественной стойкости и совершенному сотрудничеству с пользователями. Оптимизация рабочего процесса обеспечивается при помощи внедрения информационных, компьютерных, документных и технологических нововведений. Подобные действия дают возможность организовать разговор с клиентом и прийти к необходимому результату.

Вложения в развитие средств улучшения сервисного обслуживания производят передовые большие банки, расширяя клиентские услуги, что оказывает влияние на рост лояльности покупателей. Современные банковские технологии направлены на обеспечение достаточной устойчивости кредитной организации и создание максимально эффективных условий взаимодействия банка с клиентами.

Банковские технологии почти во всем облегчают процесс работы финансовой компании, делают его резвее и надежнее, устанавливают единые формы отчетности и предоставления данных, помогают сделать действенный документооборот и сотрудничество профессиональных специалистов банка.

Банковская инновация - это процесс, предусматривающий, с одной стороны, модернизацию процесса предоставления услуг, продуктов, которые удовлетворяют потребителей банка, а с другой стороны, увеличение объемов оказываемых услуг и повышение доходов [5].

Как показывает современная тенденция развития сферы банковских услуг в мире, перед большим количеством крупных и отделений финансовых учреждений банки будущего должны быть социальными и инновационными, способными удовлетворить потребности потребителей. Чтобы внедрить данные особенности в свою деятельность, банку необходимо увеличить объем выделяемых на эту отрасль средств, быть первым на рынке и уметь качественно реализовывать инновации (рис. 1).

Наиболее исчерпывающим является определение банковской технологии как сделанной банком системы производства и доставки банковского продукта целевой аудитории для удовлетворения ее потребностей. Банковская технология - это упорядоченная совокупность функционально и информационно взаимосвязанных операций, действий, работ и процедур, обеспеченных необходимыми ресурсами, реализуемых техническими и человекомашинными системами и направленных на достижение эффективности банковских операций.

Банковская технология представляет собой способ организации целесообразной практической деятельности, опирающейся на совокупность приемов и методов, направленных на принятие оптимальных управленческих решений, создание банковского продукта и оказание банковской услуги. Появление данной формулировки обусловлено тем, что за последние пятна- 
дцать лет возросло значение средств и [7].

методов реализации банковских задач

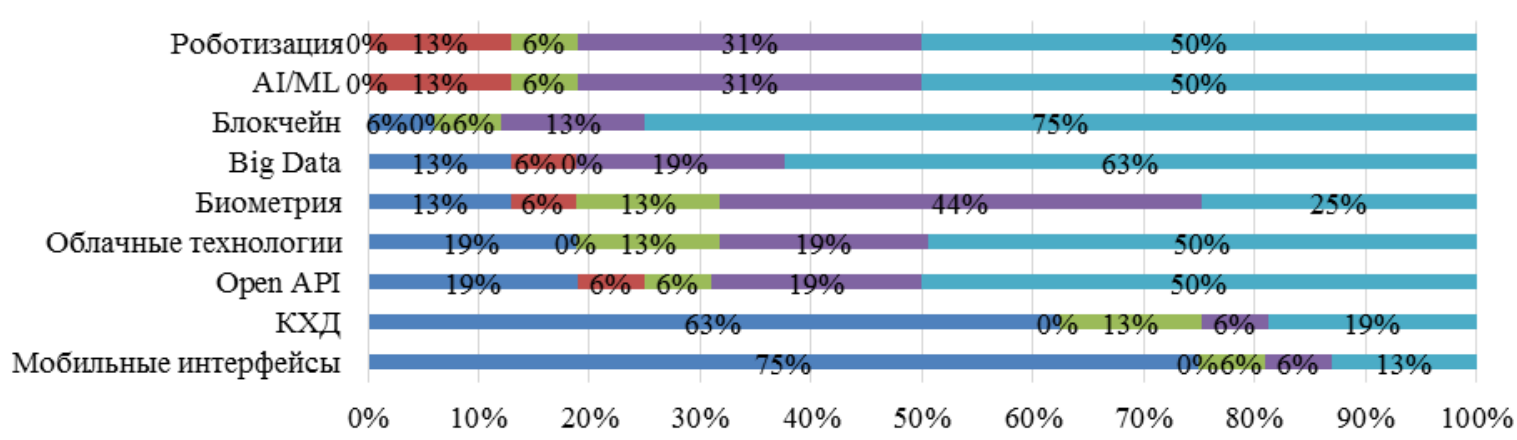

ఐ Промышленное решение реализовано или технология используется на постоянной основе

ш Пилотный проект успешно реализован

ఐ Пилотный проект направлен на успешную реализацию

п Планируется реализация пилотного проекта с использованием технологии

- Технология не используется

Рис. 1. Показатели уровня использование банками современных технологий

Источник: составлено на основе [6]

Для обеспечения банками тенденции всеохватывающей автоматизации бизнеса, необходимо обеспечить процесс непрерывного улучшения банковских технологий, которые, в свою очередь, нерушимо соединены с современными IT продуктами.
Существует ряд определенных принципов банковских технологий, которые выступают как основа для поддержки и развития банковского бизнеса (табл. 1).

Таблица 1

\section{Определенные принципы банковских технологии}

\begin{tabular}{|c|c|}
\hline Принцип & \multicolumn{1}{|c|}{ Основные критерии проявления } \\
\hline $\begin{array}{c}\text { Доступность } \\
\text { технологий }\end{array}$ & $\begin{array}{l}\text { Это поспособствует открытому взаимодействию с разными внешними } \\
\text { систами, обеспечит выбор наиболее подходящей программной плат- } \\
\text { формы, ее удобство в эксплуатации и переноске на другие аппаратные } \\
\text { средства. }\end{array}$ \\
\hline $\begin{array}{c}\text { Масштаб- } \\
\text { ность }\end{array}$ & $\begin{array}{l}\text { По мере развития бизнес-процессов будет проходить усложнение и } \\
\text { расширение функцинальных модулей системы. }\end{array}$ \\
\hline $\begin{array}{c}\text { Возмож- } \\
\text { ность }\end{array}$ & $\begin{array}{c}\text { Возможность алгоритмических настроек, моделирование банка и его } \\
\text { бизнес процессов. }\end{array}$ \\
\hline $\begin{array}{c}\text { Принцип } \\
\text { построения }\end{array}$ & $\begin{array}{l}\text { Также существует модульный принцип построения, который способ- } \\
\text { нейшим нартой конфигурации систем под определенный заказ с даль- }\end{array}$ \\
\hline Доступ & $\begin{array}{c}\text { Доступ к данным каждому пользователю онлайн и возможность реа- } \\
\text { лизации функций в одном общем информационном пространстве. }\end{array}$ \\
\hline
\end{tabular}


Завершение табл. 1

\begin{tabular}{|c|c|}
\hline Удобство & $\begin{array}{c}\text { Удобство настроек модуля банковской системы и возможность под- } \\
\text { строиться к потребностям каждого банка. }\end{array}$ \\
\hline $\begin{array}{c}\text { Развитие и } \\
\text { улучшение }\end{array}$ & $\begin{array}{l}\text { Полтянное развитие и улучшение системы на основе ее фундамен- } \\
\text { троцесо переосмысления и радикального перепроектирования бизнес- } \\
\text { хозяйственной и финансово-экономической деятельности }\end{array}$ \\
\hline
\end{tabular}

Источник: составлено на основе [8]

Развитие и модернизация формирования кредитно-финансовой отрасли впрямую зависит от IT продуктов. Естественно, сейчас мир не стоит на месте и всё меняется каждый день. Денежно-финансовые учреждения должны вкладывать в развитие технологий, по-другому им просто придется уступать дорогу больше развитым компаниям или организациям.

В банках разрабатываются новые модели анализа факторов риска и уровня инвестиционной привлекательности проектов, для того, чтобы поддержать общий уровень конкурен- тоспособности. Другими словами, банковские технологии включают в себя систему действий, с помощью которых обеспечивается организация сервиса, соответствующего запросам потребителей. Современные информационные технологии в значительной степени влияют на бизнеспроцессы в банках, выводят их на принципиально новый качественный уровень [9]. Банковские технологии и IT связаны неразрывно, так как банковские технологии базируются на информационных (рис. 2).

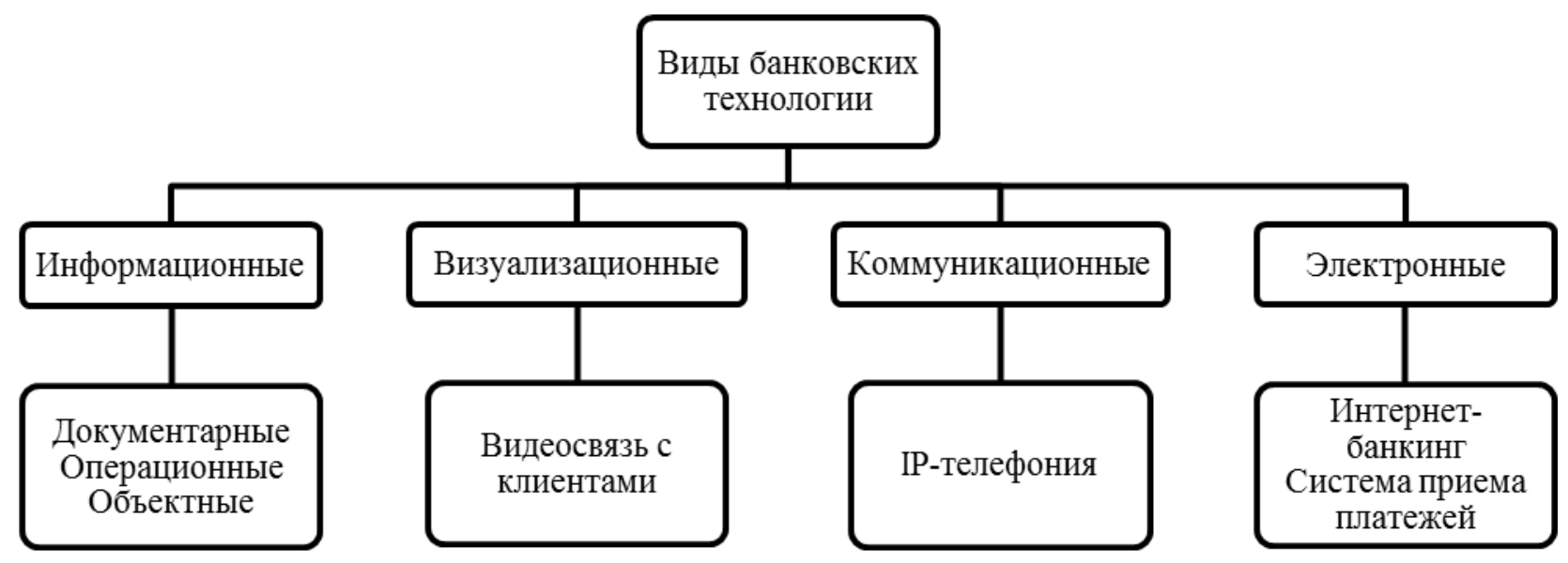

Рис. 2. Виды банковских технологий

Источник: составлено на основе [3]

Банковские и информационные технологии помогают настроить и обеспечить автоматизацию банковского бизнеса [10].

Для того, чтобы не оказаться в положении технологического отставания, банкам необходимо заниматься автоматизацией направлений своей деятельности. Конкурентоспособность банка в современных реалиях во многом определяется уровнем его технологичности [11]. 
Внедрение инноваций во все сферы деятельности экономических субъектов, переход экономики на инновационный путь развития, стали одними из приоритетов государственной политики, влияющих на экономический рост, развитие и структурные сдвиги в экономике, а также важнейшим инструментом, поддерживающим конкурентоспособность национальной экономики, в том числе и банковского сектора [12, с. 153]. Поэтому, основным содержанием нового этапа в развитии банковского сектора должно стать повышение качества банковской деятельности, включающее расширение состава банковских продуктов и услуг, рост их качества и совершенствование способов предоставления, повышение долгосрочной эффективности и устойчивости бизнеса. Инвестиции и инновации стали сутью современного развития не только в банковском деле, но и во всех отраслях экономики [13, с. 86]. Таким образом, разработка и внедрение финансовых инноваций и технологий в банковский сектор экономики еще не потеряла свою актуальность, а наоборот обретает необычную актуальность.

Надежные и безопасные платежные системы способствуют повышению стабильности финансовой системы государства в целом, обеспечивают эффективное использование финансовых ресурсов и улучшают ликвидность финансовых рынков, а также гарантируют своевременный расчет между продавцами и покупателями.

Опыт создания новых банковских продуктов, услуг и технологий на рынке Республики Казахстан опирается на мировой опыт. Любые банковские инновации на банковские продукты и услуги не являются иннова- циями по истечении некоторого периода времени в полном смысле из-за отсутствия процедуры патентов, так как занимают широкую нишу на рынке и в среде конкурентов.

В настоящее время на территории Республики Казахстан функционируют две национальные платежные системы: Межбанковская система переводов денег (МСПД) и Система межбанковского клиринга (СМК) (рис. 3).

В целом, за январь-февраль 2021 года через Межбанковскую систему переводов денег и Систему межбанковского клиринга было проведено 8,8 млн. транзакций на сумму 114,3 трлн. тенге. По сравнению с аналогичным периодом 2020 года количество платежей в указанных платежных системах увеличилось на 22,5\% (на 1614,1 тыс. документов), сумма платежей увеличилась на $0,8 \%$ (на 0,9 трлн. тенге).

В 2020 году АО «Kaspi Bank» возглавил рейтинг крупнейших казахстанских банков, который последние годы занимается созданием инновационных сервисов и продуктов в банковском секторе. В ноябре 2014 года запущен «Kaspi Магазин» - онлайнагрегатор для сравнения цен и покупки товаров в кредит. В августе 2016 года презентована программа Kaspi Red, предоставляющая рассрочку для потребительских покупок.

В течение 2016-2017 годов начали действовать Kaspi Gold и приложение Kaspi.kz, которые изменили рынок безналичных платежей для пользователей. На начало 2020 года число активных пользователей Kaspi.kz составило более 6 млн., Kaspi Gold - более 4,5 млн. (рис. 4) [15]. 
МСПД и Система межбанковского клиринга

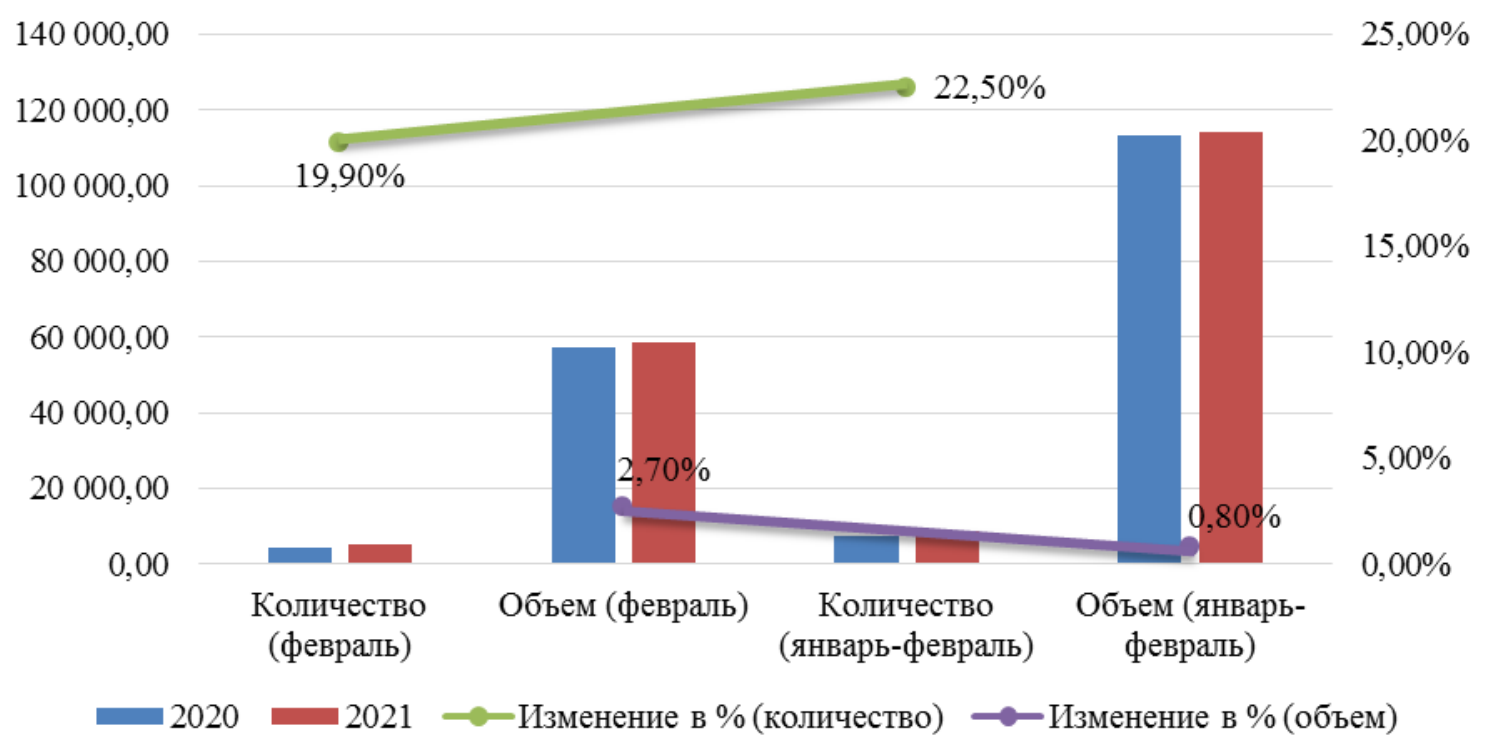

Рис. 3. Показатели работы национльных платежных систем (тыс. транзакичй и млрд. тг. соответственно)

Источник: составлено на основе [14]

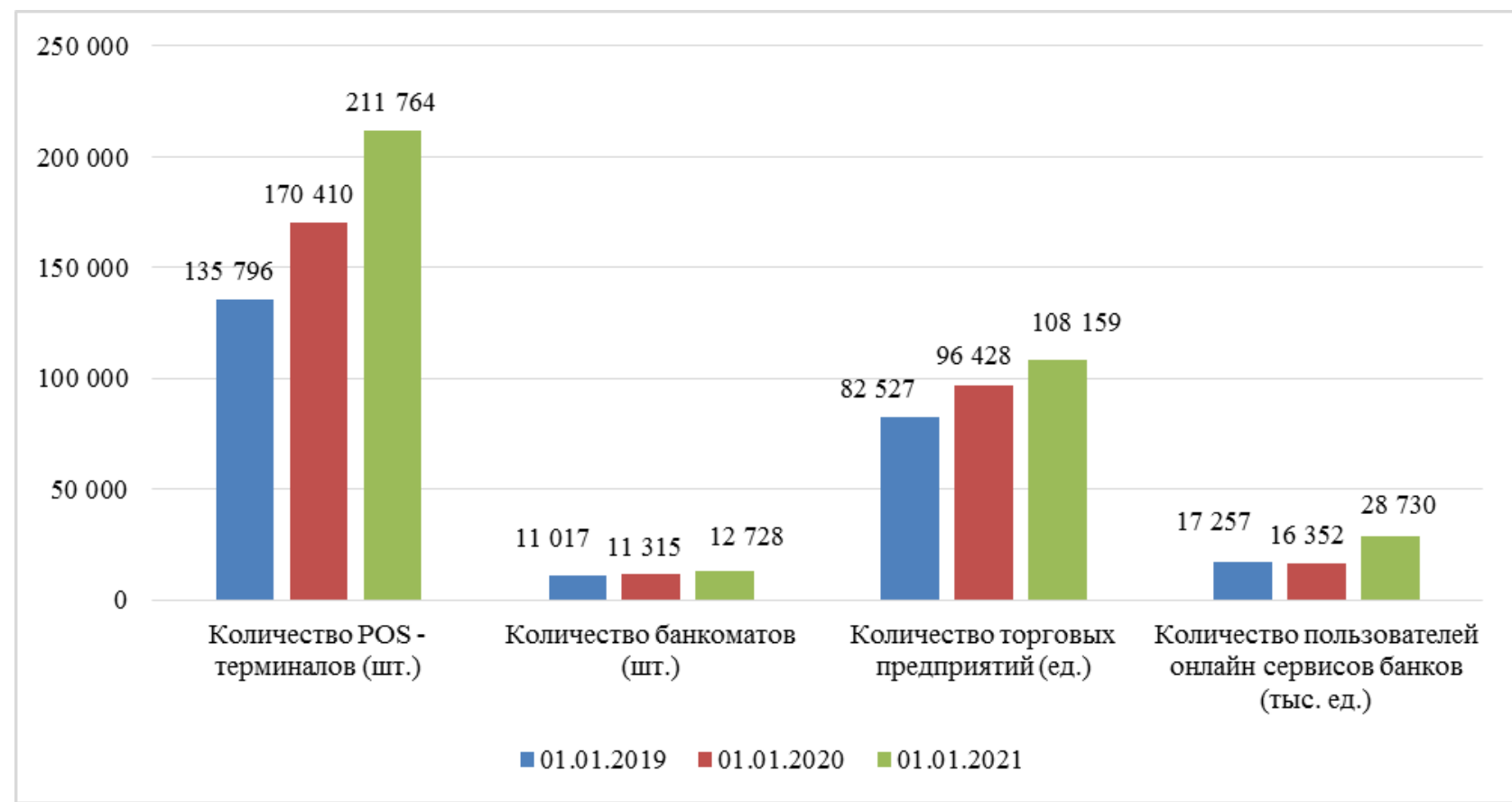

Рис. 4. Количество POS-терминалов, банкоматов, торговых предприятий и пользователей онлайн сервисов банков в течение 2019-2021 годов Источник: составлено на основе [14]

По состоянию на 01.01.2021 года больше всего POS-терминалов установлено в Алматы - 59189, в НурСултане - 35749, в Карагандинской области - 16771 терминалов. Меньше всего их в Кызылординской области -
3832 и в Жамбылской области - 4798 терминалов (рис. 5).

Большая часть банкоматов находится в городе Алматы, там - 2463 банкоматов. На втором месте, город НурСултан - 1552 банкоматов и в Турке- 
станской области и в городе Шымкент находится 1092 банкоматов. Меньше всего банкоматов находится в Северо-

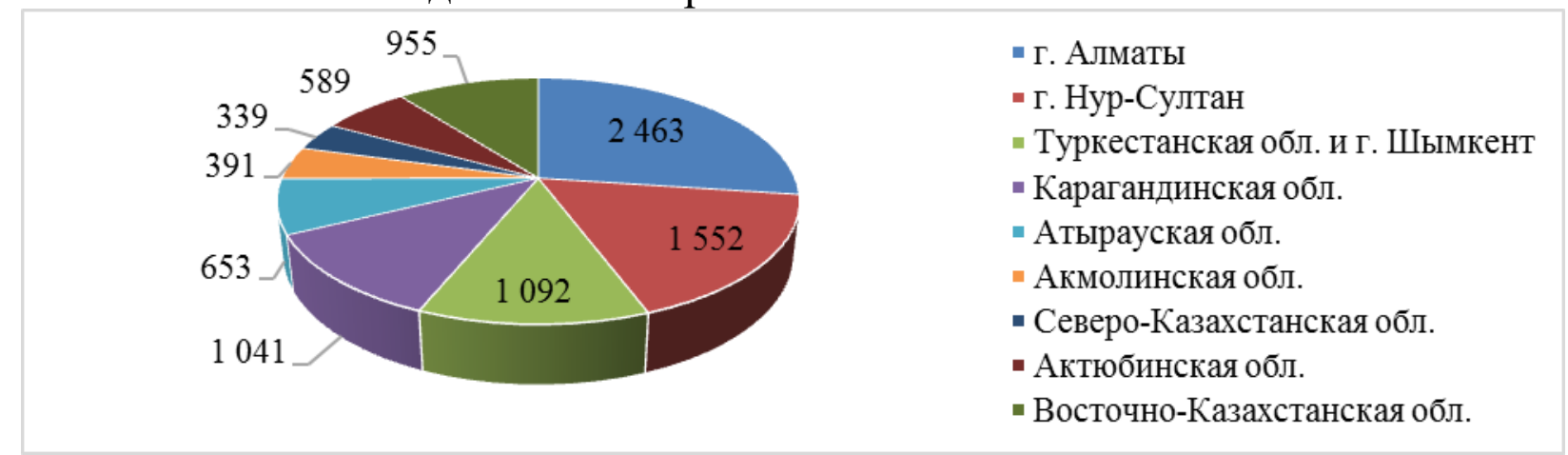

Казахстанской области, там всего 339 банкоматов.

Рис. 5. Количество банкоматов, по состоянию на 01.01.2021года

Источник: составлено на основе [14]

Банками Казахстана и АО «Каз- 2021 года на территории Казахстана, почта» предоставляются услуги по пе- составляет 24,5 \%от общего количереводам денег через такие системы, ства и 7,6 \% от общей суммы перевокак Золотая корона, Вестерн Юнион, дов денег, отправленных посредством Юнистрим, Contact, Faster, СДП. Доля переводов денег, отправMoneyGram и иные СДП. Доля пере- ленных за рубеж, составляет 75,5 \% и водов денег, проведенных в феврале 92,4\% соответственно (рис. 6) [16].
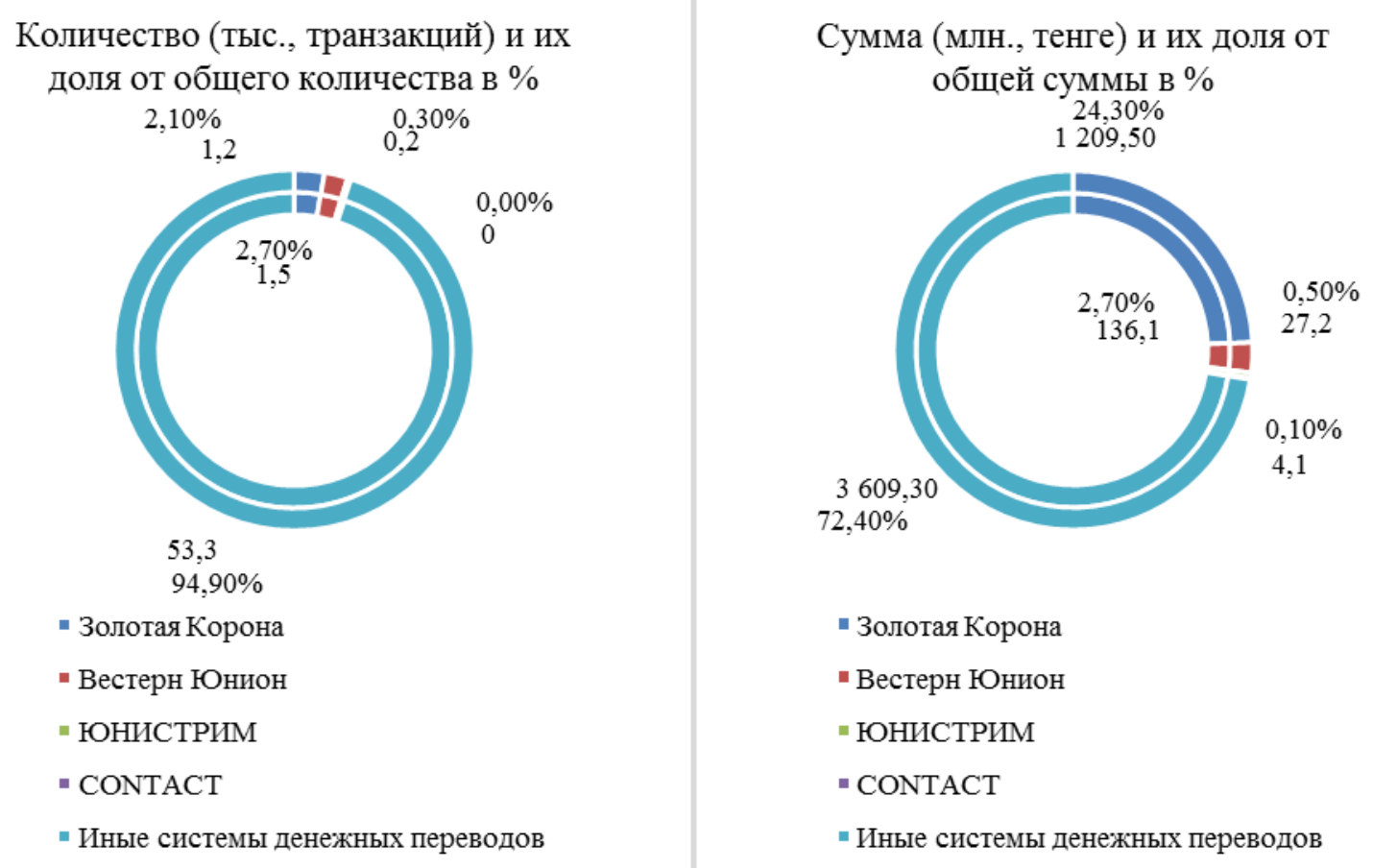

Рис. 6. Характеристика переводов на территории Казахстана (в разрезе систем денежных переводов) по состоянию на 01.02.2021 года

Источник: составлено на основе [16]

На территории Казахстана в февра- транзакций на сумму 4 986,2 млн. тенле 2021 года было проведено 56,1 тыс. ге (рис. 7). 

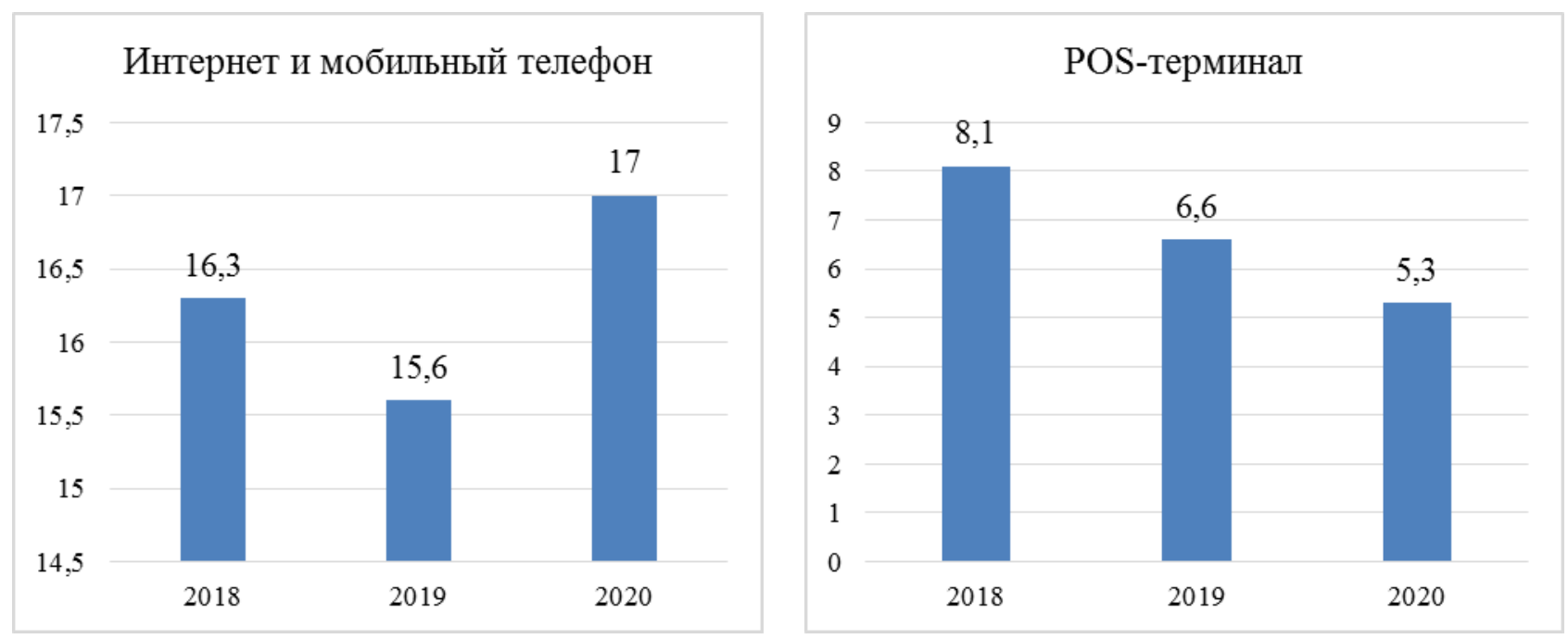

Рис. 7. Средний размер безналичного платежа, совершенного с карты через интернет и мобильный и средний чек оплаты через POS-терминал, в течение января-ноября 2020 года

Источник: составлено на основе [17]

Средний размер одного безналичного платежа, совершенного с карты через интернет и мобильный телефон, в 2020 году составил 17 тысяч тенге (рис. 7), увеличившись по сравнению с предыдущим годом почти на полторы тысячи тенге. В то же время, средний чек оплаты через POSтерминал, сократился до 5,3 тысячи тенге. Доля платежей, совершенных на территории Казахстана через интернет и мобильные телефоны, а также через POS-терминалы составляют $99,6 \%$ от всего объема безналичных платежей. При этом, за перыод с января по ноябрь 2020 года 24,4 триллиона тенге было потрачено держателями карт через интернет и мобильные телефоны, и только 5,4 триллиона - через POS-терминалы.

Средний размер одного безналичного платежа, совершенного с карты через интернет и мобильный телефон, в 2020 году составил 17 тысяч тенге (рис. 7), увеличившись по сравнению с предыдущим годом почти на полторы тысячи тенге. В то же время, средний чек оплаты через POS-терминал, сократился до 5,3 тысячи тенге. Доля платежей, совершенных на территории Казахстана через интернет и мобильные телефоны, а также через POS-терминалы составляют 99,6\% от всего объема безналичных платежей. При этом, за перыод с января по ноябрь 2020 года 24,4 триллиона тенге было потрачено держателями карт через интернет и мобильные телефоны, и только 5,4 триллиона - через POSтерминалы.

В настоящее время популярность банковских приложений - мобильного и онлайн банкинга - постоянно растет. Одна из причин - появление цифровых альтернатив, что позволяет клиентам банков не тратить время на походы в отделение. Кроме того, среди общего числа клиентов финансовых организаций растет число молодых пользователей, так называемых миллениалов. 
Рассмотрим еще одно важное направление развития банковских технологий на современном этапе развитие отношений с клиентами и индивидуализация данных отношений (CRM - customer relationship management). Технологии CRM дают знание запросов и потребностей клиентов и позволяют выбрать наиболее целесообразные способы их обслуживания. Это, в свою очередь, делает экономическую деятельность банка более активной и продуктивной. Управление клиентскими отношениями дает возможность банку получать дополнительный доход от использования знаний о клиентах. Важнейшей сложностью внедрения CRM-систем в банки является интеграция CRM и других систем банка.

Таким образом, основной из тенденций развития банковских инноваций является повышенное внимание к переходу от ценовых и количественных характеристик финансовых продуктов к сервисным и качественным характеристикам, таким как индивидуальное качественное и быстрое обслуживание клиента.

В настоящее время много интернетпользователей употребляет системы интернет-банкинга как добавочный инструмент управления своими средствами. Все-таки исследование представляет, что чем энергичнее интернет-пользователи будут усваивать новейшие технологии интернетбанкинга, тем активнее будет расти их доверие к сходным системам. Одной из перспективных технологий притягивания интернет пользователей в виртуальные банки в наши дни является технология полной комплексной работы с несколькими счетами с одного Веб-сайта, пропускающая необхо- димость управления каждым отдельным счетом с разных интернетпорталов. Интернет и вообще банковские услуги на дому проявляют свое влияние на отделения банков, банкоматы и банковские центры обращения. Тем не менее, сегодня системы такого типа еще не очень популярны. Формирование таких систем сильно замедляется отсутствием четких правовых основ коммерческих расчетов в киберпространстве. Все же, остаются актуальными проблемы безопасности таких расчетов. Нужно подметить, что качество линий в Казахстане пока ограничивает надежность работы в режиме онлайн. Скорости передачи ограничены, что ведет к главному росту времени при работе с большими объемами данных, в особенности через международные шлюзы.

Одна из следующих рекомендации по улучшению банковских технологий, - усовершенствование искусственного интеллекта. Искусственный интеллект поможет банкам автоматизировать процессы и повысить качество обслуживания клиентов.

Искусственный интеллект продолжает быстро распространяться в отраслях, которые в значительной степени зависят от данных, - это практически все отрасли промышленности. Сектор финансовых услуг не является исключением.

Исследование PricewaterhouseCoopers фиксирует, что 52\% руководителей индустрии финансовых услуг в настоящее время вкладывают существенные инвестиции в искусственный интеллект, и 72\% лиц, принимающих бизнес-решения, считают, что искусственный интеллект станет основным бизнес- 
преимуществом для субъектов финансовой сферы в будущем [19].

Таким образом, клиентоориентированной целью внедрения искусственного интеллекта в банковский сектор является обеспечение персонализированных и высококачественных условий для формирования удовлетворенности клиентов параллельно с эффективными и экономящими время услугами.

Следующее решение по развитию банковских технологии, это - персонализация предложений. Современный цифровой банк, используя нынешние облачные системы, может дать каждому клиенту услуги именно в той форме, в которой они им будут востребованы. Например, курьер доставит документы, заказанные через мобильное приложение, автомобиль банкомат позволит депонировать наличные, а облачная платформа интернет банкинга предоставит всю информацию по счету, включая сервисы по проверке контрагентов. И все это будет создано с одной целью предоставить удобство клиенту при их использовании [20, с. 2].

Следовательно, в условиях инновационной глобализации банкам просто необходимо пользоваться новыми инновационными технологиями. Чтобы выстоять в глобальной конкуренции, казахстанские банки должны улучшить уже имеющиеся новые технологии и как можно быстрее внедрить новые технологии, с помощью которых будет выстоять в глобальной конкуренции.

Выводы. В нашей стране совершается поэтапный процесс изменения схемы и тактик убеждений взаимодействия с клиентами в большинстве банков. Немалая часть банковских орга- низаций в настоящее время способна предоставлять комплексное обслуживание: выгодное карточное обслуживание, дистанционное обслуживание и обслуживание с помощью мобильных приложений. Для улучшения процесса развития банковской системы в условиях рынка необходимо совершенствовать применение банковских технологий. Внедрение новой банковской технологии в нашей стране находиться в неудобном положении из-за отсутствие своих аналитических отделов, умелых и высокопрофессиональных специалистов, способных формировать результативные финансовые модели, приспособить инструменты, которые предлагают специалисты из многих западных стран.

Сфера банковской системы наиболее активно употребляет информационные технологий. Развитие банковского бизнеса без использования информационных технологий невозможно, потому что реализация задач по внедрению новых банковских услуг и продуктов, организация взаимодействия с клиентами, контрагентами, биржами напрямую связана с информационными технологиями. Более того, использование информационных технологий является одним из ключевых факторов эффективности и конкурентоспособности современного банка.

В настоящее время банковская система переходит на качественно новый этап своего развития, когда в условиях жесткой конкуренции банки для сохранения своего положения на рынке должны создавать принципиально новые организационные структуры, использовать новейшие банковские технологии. 
В заключении можно сказать, что развитие банковских технологий необходимо. В настоящее время существует ряд проблем по внедрению новых информационных технологий, в основном касающихся способов защиты передаваемой информации. Их внедрение позволит банкам избавиться от недостатков существующих систем, оптимизировать издержки на проведение различных операций, ис- пользовать преимущества за счет тиражирования технологически апробированных решений во всех подразделениях банка, а также уверенно прогнозировать планомерный рост своей деятельности, конкурентоспособные условия обслуживания клиентов и укрепления позиции на рынке кредитных организаций.

\section{Список использованной литературы}

1. Шамин Е.А., Генералос И.Г., Завиваев Н.С., Черемухин А.Д. Сущность информатизации, ее цели, субъекты и объекты. Вестник НГИЭИ. 2015. № 11. C.99-107.

2. Тавасиев А.М., Мехряков В.Д., Эриашвили Н.Д. Банковское дело. Управление и технологии. М.: Юнити-Дана, 2017. 56 с.

3. Горелая Н.В., Карминский А.М. Основы банковского дела. Учебное пособие. М.: ИД «ФОРУМ» ИНФРА-М, 2013. 272 с.

4. Макаров А.Д., Ломакин А.Ю. Управление инновациями и инновационными технологиями в банковском менеджменте. Ученые записки Санкт-петербургского университета управления и экономики. 2014. № 4. C. $38-46$.

5. Охлопков А.В. Инновации в сфере предоставления банковских услуг: дис. ...канд.экон.наук : 08.00.10. Москва, 2011.

6. Қаржылық технологиялар мен инновацияларды дамытудың 2020-2025 жылдарға арналған тұжырымдамасы, Нұр-Сұлтан, 2020.

7. ГОСТ Р 8.561-95. Государственная система обеспечения единства измерений. Метрологическое обеспечение банковских технологий. Общие положения. URL: https://docs.cntd.ru/document/1200026048. (дата обращения: 12.03.2021)

8. Пинина К.А. Современные информационные банковские технологии. Тенденции и перспективы развития банковской системы в современных экономических условиях: материалы межд. научн.-практ. конфр. Казань, 2018. С. 174176. 
9. Самсонова Е. А., Астахов В. Ю., Аджиева А. Ю. Информационные технологии как инструмент совершенствования банковского сектора. Аллея науки. 2018. № 4. С. 932-934.

10. Ермакова Л.В., Гудкова О.В., Дворецкая Ю.А. Инновационные технологии на рынке банковских услуг. Бюллетень науки и практики. 2018. № 5. С. 424-429. 11. Комарова Л.В. Применение информационных технологий в банковской сфере. Экономика и управление: проблемы, решения. 2015. № 3. С. 101-103. 12. Жирнова А.М., Зиновьева Н.М. Инновационный фактор как основа развития предпринимательства. Инновационные подходы к решению социальноэкономических, правовых и педагогических проблем в условиях развития современного общества: материалы I междунар. науч.-практ. конф., 26-27 ноября 2015 г. Старый Оскол: АНОО ВО ВЭПИ, 2015.

13. Зиновьева Н.М. Основы формирования инвестиционной политики коммерческого банка. Новая наука: современное состояние и пути развития. Стерлитамак: РИЦ АМИ. 2016. Ч. 1.

14. Национальный Банк Казахстана URL: https://www.nationalbank. kz/ru?switch=kazakh_ (дата обращения: 12.03.2021)

15. Forbes: Kaspi Bank URL: https://forbes.kz//ranking/object/8_ (дата обращения: 12.03.2021)

16. Межбанковская система переводов денег (статистика за февраль 2021 года) URL: https://finreg.kz/?docid=672\&switch=russian (дата обращения: 12.03.2021)

17. Новости Казахстана URL: https://www.nur.kz/ (дата обращения 12.03.2021) 18. Зорин Г.Е. Искусственный интеллект и его применение в банковской сфере. Вестник Российского университета кооперачии. 2020. 1(39). С. 31-36.

19. Василенко О. А. Основные тенденции развития новых банковских продуктов и услуг в России на современном этапе. Вестник науки и образования. 2018. № 10(46). С. 33. 